\title{
Proteocephalidean Larvae (Cestoda) in Naturally Infected Cyclopid Copepods of the Upper Paraná River Floodplain, Brazil
}

\author{
Dina Lúcia Morais Falavigna/ ${ }^{+}$, Luiz Felipe Machado Velho*, Gilberto Cezar Pavanelli**
}

Laboratório de Parasitologia Básica, Departamento de Análises Clínicas *Laboratório de Zooplâncton **Laboratório de Ictioparasitologia, Núcleo de Limnologia, Ictiologia e Aquicultura, Universidade Estadual de Maringá, Av. Colombo 5790, Bloco I-90, sala 11, 87020-900 Maringá, PR, Brasil

The occurrence, prevalence and infection intensity of proteocephalidean larvae in naturally infected intermediate hosts of the Upper Paraná River floodplain are reported. A total of 5,206 zooplanktonic and benthic organisms were analyzed, namely cyclopid $(2,621)$ and calanoid $(1,479)$ copepods, cladocerans $(704)$, rotifers $(307)$, chironomid larvae (41) and ostracods (54). Eight cyclopid copepods - two copepodids, one male and five females comprising $0.3 \%$ of the cyclopid copepods examined, were naturally infected. The male infected belonged to a species of Paracyclops, and the females to Paracyclops sp., Thermocyclops minutus and Mesocyclops longisetus.

Key words: larvae - Proteocephalidea - cyclopid copepods - Upper Paraná River - Brazil

The life cycles of certain proteocephalidean cestodes have been studied in the Northern Hemisphere for the last 50 years, mainly by Wagner (1954), Fischer (1968), Priemer (1987) and Scholz (1999). The ontogenetic development of proteocephalids could start with the dissemination of the eggs in water. When ingested by an aquatic organism, generally a copepod, the oncosphere released from egg rupture actively penetrates the gut wall. Within the body cavity, the oncosphere develops into a plerocercoid or a merocercoid (Chervy 2002). As a component of the fish diet, the copepod transmits the merocercoid to suitable fish host, where the larva may migrate parenterally, becoming or not encapsulated, or it may develops into an adult if it stops in the intestinal lumen (Smyth 1994).

Pavanelli and Machado dos Santos (1991) and Rego et al. (1999) have already reported adults of proteocephalideans in fish species of the Upper Paraná River floodplain. Encapsulated merocercoids have recently been isolated from the intestinal wall, mesentery and peritoneum of Gymnotus spp. ("morenita", Gymnotidae) (Falavigna et al. 2000), from the intestinal wall and mesentery of Loricariichthys platymetopon ("cascudo-chinelo", Loricariidae) (Schäffer et al. 1992), Pseudoplatystoma corruscans ("pintado", Pimelodidae) (Rego \& Gibson 1989), and Hoplosternum littorale ("caboja or tamboatá", Callichthyidae) (Falavigna et al. 2000). In order to contribute to the knowledge of the life cycle of proteocephalids in the Upper Paraná River floodplain, potential intermediate hosts of proteocephalidean cestodes were examined.

Financial support: Programa de Pós-graduação em Ecologia de Ambientes Aquáticos Continentais

${ }^{+}$Corresponding author. Fax: +55-44-261.4490. E-mail: falavigna@wnet.com.br ordlmfalavigna@uem.br

Received 27 May 2002

Accepted 21 October 2002
A total of 5,206 specimens of zooplanktonic and benthic organisms were collected between March 1999 and June 2000. They comprised cyclopid copepods $(2,621)$, calanoid copepods $(1,479)$, cladocerans $(704)$, rotifers (307), larvae of chironomids (41) and ostracods (54). Zooplankton $68 \mu \mathrm{m}$-mesh nets were used; collection occurred from 6 to 8 a.m. and from 5 to 7 p.m. (LansacTôha et al. 1992).

The samples were collected in semi-lotic (Baía River) and lentic (Garças Lake; Leopoldo Backwater and Pau Véio Backwater) environments (Fig. 1). Specimens were examined on a lamina with a thin layer of water under light microscope after narcotization by $0.7 \%$ carbonated water.

Ecological terms were those suggested by Bush et al. (1997). The identification of merocercoids was based on Rybicka (1966), Jarecka (1975), Scholz (1999) and Chervy (2002) and the identification of cyclopid copepods on Reid (1985).

Eight cyclopid copepods, i.e. $0.3 \%$ of the copepods examined, harbored merocercoids; two were copepodids, one was male and five females (Table). The infected male was identified as Paracyclops sp., and the females belonged to the following taxa: Paracyclops sp., Thermocyclops minutus Lowndes, 1934 and Mesocyclops longisetus Thiébaud, 1914.

Only one merocercoid was observed in each naturally infected copepod (Fig. 2a). Developmental degree of larval phases ranged from a hexacant embryo, measuring $27.6 \mu \mathrm{m}$, to fully formed merocercoids, measuring 276-389 $\mu \mathrm{m}$ (Fig. 2a, b). They were found freely moving within the first cephalothoracic segment of the body cavity of copepods.

Species identification of larvae was impossible. However, it may be observed that the monocephalic and acetabulate larvae presented invaginated scolex provided by four suckers $(86 \pm 3 \mu \mathrm{m})$ and an apical end organ $(67 \pm$ $2 \mu \mathrm{m}$ ), lacking a primary lacuna and a cercomer (Fig. 2b). These larval cestodes were also similar to proteo- 
cephalidean larvae obtained from experimental infection of copepods (Falavigna 2002).

Infected copepods were found in March and December 1999 and February 2000 (summer and spring) in the Baía River and in the Pau Véio Backwater, at a water temperature ranging from 24 to $30^{\circ} \mathrm{C}$. Flooding period and fish reproduction in the region occurred between October and February.
This is the first report of merocercoids of proteocephalidean tapeworms in naturally infected copepods in Brazil natural environments, but Békési et al. (1992) have already found proteocephalidean larvae in Diaptomus sp. from artificial environments (aquaculture tanks) placed in Northeast Brazil.

Low prevalence $(0.3 \%)$ found here was similar to those reported by Doby and Jareka (1966) and Marcogliese (1995),

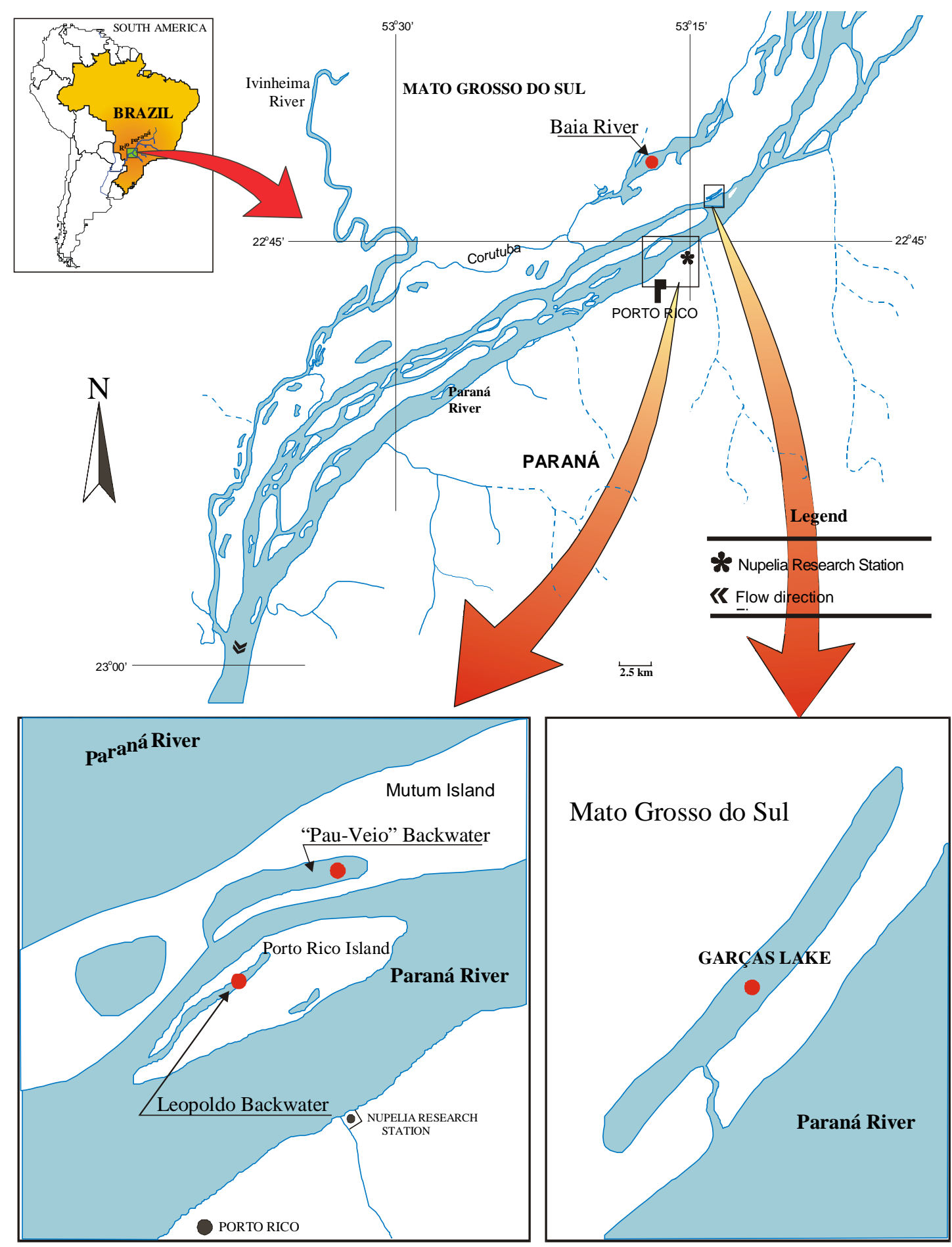

Fig. 1: collection sites in the Upper Paraná River floodplain, Brazil 
who reported rates from 0.001 to $1 \%$. There is a considerable difference between intensity of infection between natural intermediary hosts and those experimentally infected (Scholz 1999). Higher rates, found in the latter, may be explained by the absence of interferential environmental factors such as the low probability of spatial and temporal contact between copepods and proteocephalidean eggs, rapid temperature changes, the decrease in copepod mobility and the difficulty in food gathering.

The localization of a single merocercoid in the first thoracic segment of infected copepods seems to be the rule in natural infections (Scholz 1999). However, multiple infections may be obtained in an experimental way, possibly due to the greater egg availability (Falavigna 2002).

With regard to seasonality, the infected copepods were detected in the end of spring and summer. It coincided with flooding period and that of reproduction of copepods and fishes. It is acknowledged that the flooding period in the Upper Paraná River floodplain largely contributes towards the species richness and dispersion of cope- pods (Lansac-Tôha et al. 1997), while reproduction favors infection and parasitism in aquatic organisms (Dogiel 1970). According to Pavanelli et al. (1997), environmental abiotic factors (hydrological flow oscillations, temperature, dissolved oxygen concentration and turbulence of the water) and biotic factors (composition of the zooplanctonic and bentic fauna) have decisive influence on the susceptibility of fishes to parasite infections and on the epidemiology of certain species of parasites. Besides, the mating process and the egg production consumes accumulated energy and stimulates the females to feed themselves voraciously (Poulin 1996, Wedekind \& Jakobsen 1998). The dispersion of infected copepods in semi-lotic and lentic environment such as the Baía River and the Pau Véio Backwater, respectively, enhances the chance of infection of zooplanctivorous larvae and young fishes, once these places are breeding sites of Gymnotus spp., L. platymetopon, H. littorale - paratenic hosts and $P$. corruscans - definitive host of proteocephalideans in the region (Falavigna 2002).

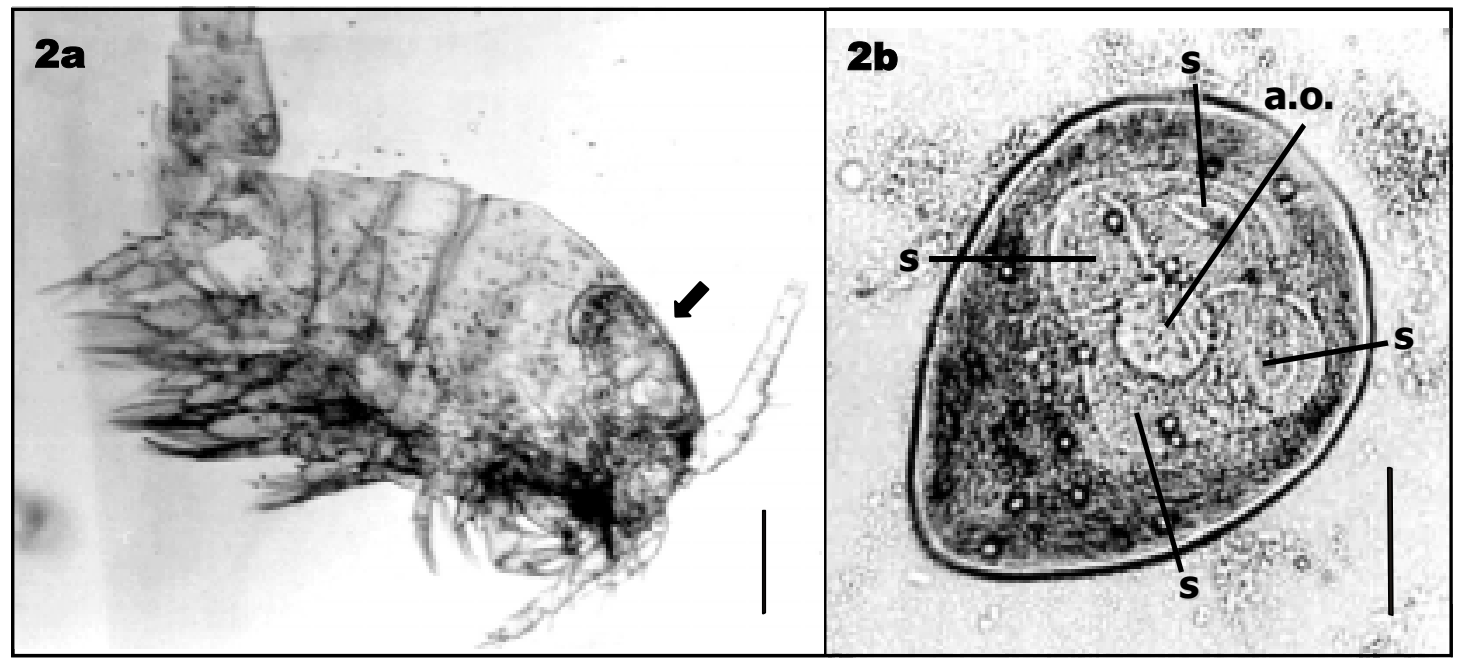

Fig. 2a: copepod with merocercoid (arrow); b: free merocercoid after release from copepod, having invaginated scolex with apical end organ (a.o.) and four suckers (s). Bar $=100 \mu \mathrm{m}$

TABLE

Merocercoids in zooplanktonic and benthic organisms collected between March 1999 and June 2000 in the aquatic environments of the Upper Paraná River floodplain, Brazil

\begin{tabular}{llrrr}
\hline Organisms & Stage & $\mathrm{N}$ & $\mathrm{Ni}$ & Prevalence $(\%)$ \\
\hline Cyclopid copepods & Immature $^{a}$ & 1,565 & 2 & 0.1 \\
& Males & 406 & 1 & 0.3 \\
Subtotal & Females & 650 & 5 & 0.8 \\
\hline Calanoid copepods & & 2,621 & 8 & 0.3 \\
& Immature $^{a}$ & 516 & - & - \\
Subtotal & Adults & 963 & - & - \\
Cladocerans & & 1,479 & - & - \\
Rotifers & & 704 & - & - \\
Ostracoda & & 307 & - & - \\
Chironomida larvae & 54 & - & - \\
\hline Total & & 41 & - & - \\
\hline
\end{tabular}

$\mathrm{N}$ : number of examined; $\mathrm{Ni}$ : number of infected; $a$ : nauplii and copepodids 


\section{REFERENCES}

Békési L, Feitosa VA, Cabral FAB 1992. Metacestodosis caused by plerocercoids of Proteocephalidea (Cestoda) in fish fry cultured in large scale in the Brazilian Northeast. Parasitol Hung 25: 9-13.

Bush AO, Lafferty KD, Lotz JF, Shostak AC 1997. Parasitology meets ecology on its own terms: Margolis et al revisited. J Parasitol 83: 575-583.

Chervy L 2002. The terminology of larval cestodes or metacestodes. Syst Parasitol 52: 1-33.

Doby JM, Jarecka L 1966. Complément à la connaissance de la morphologie et de la biologie de Proteocephalus macrocephalus (Creplin 1825), cestode parasite de l'Anguille. An Parasitol 41: 429-442.

Dogiel VA 1970. Ecology of the parasites of freshwater fishes. In VA Dogiel, GK Petrushevski, YI Polyanski (eds), Parasitology of Fishes, TFH Publications, Hong Kong, p. 1-47.

Falavigna DLM 2002. Aspectos do Ciclo Evolutivo de Proteocefalídeos (Platyhelminthes: Cestoda) Parasitas de Peixes e Microcrustáceos da Planície de Inundação do Alto Rio Paraná, PhD Thesis, Universidade Estadual de Maringá, $91 \mathrm{pp}$.

Falavigna DLM, Takemoto RM, Pavanelli GC 2000. Resultados preliminares do ciclo evolutivo de cestóides parasitas de Pseudoplatystoma corruscans da planície de inundação do Alto rio Paraná, Brasil. Resumos do II Encontro LatinoAmericano de Patologistas de Organismos Aquáticos e VI Encontro Brasileiro de Patologistas de Organismos Aquáticos, Florianópolis, p.133.

Fischer H 1968. The life cycle of Proteocephalus ambloplitis Bangham (Cestoda) from smallmouth bass, Micropterus dolomieui Lacépède. Can J Zool 46: 559-579.

Jarecka L 1975. Ontogeny and evolution of cestodes. Acta Parasitol Pol 23: 93-114.

Lansac-Tôha FA, Bonecker CC, Velho LFM, Lima AF 1997. Composição, distribuição e abundância da comunidade zooplanctônica. In AEA de M Vazzoler, AA Agostinho, NS Hahn (eds), A planície de Inundação do Alto rio Paraná: Aspectos Físicos, Biológicos e Sócio-econômicos, EDUEM, Maringá, p. 117-155.

Lansac-Tôha FA, Lima AF, Thomaz SM, Roberto MC 1992. Zooplâncton de uma planície de inundação do rio Paraná. I. Análise qualitativa e estrutura da comunidade. Rev Unimar 14: $35-55$.
Marcogliese DJ 1995. The role of zooplankton in the transmission of helminth parasites to fish. Ver Fish Biol Fisher 5: 336-371.

Pavanelli GC, Machado dos Santos MH 1991. Proteocefalídeos parasitas de peixes, em especial pimelodídeos, do rio Paraná, Paraná. Rev Unimar 13: 163-175.

Pavanelli GC, Machado MH, Takemoto RM 1997. Fauna helmíntica de peixes do rio Paraná, região de Porto Rico, Paraná. In AEA de M Vazzoler, AA Agostinho, NS Hahn (eds), A Planície de Inundação do Alto Rio Paraná: Aspectos Físicos, Biológicos e Sócio-econômicos, EDUEM, Maringá, p. 307-329.

Poulin R 1996. Helminth growth in vertebrate hosts: does host sex matter? Int J Parasitol 26: 1311-1315.

Priemer J 1987. On the life cycle of Proteocephalus exiguus (Cestoda) from Salmo gairdneri (Pisces). Helminthologia 24: 75-85.

Rego AA, Gibson D 1989. Hyperparasitism by helminths: new records of cestodes and nematodes in proteocephalid cestodes from South American siluriforms fishes. Mem Inst Oswaldo Cruz 84: 371-376.

Rego AA, Chubb JC, Pavanelli GC 1999. Cestodes in South America freshwater teleost fishes: keys to genera and brief description of species. Rev Bras Zool 16: 299-367.

Reid JW 1985. Chave de identificação para as espécies continentais sul-americanas de vida livre da ordem Cyclopoda (Crustacea: Copepoda). Bol Zool Univ São Paulo 9: 17143.

Rybicka K 1966. Embryogenesis in cestodes. Adv Parasitol 4: 107-186.

Schäffer GV, Rego AA, Pavanelli GC 1992. Peritoneal and visceral cestode larvae in Brazilian freshwater fishes. Mem Inst Oswaldo Cruz 87: 257-258.

Scholz T 1999. Life cycles of species of Proteocephalus, parasites of fishes in the Palearctic Region: a review. J Helminthol 73: 1-19.

Smyth JD 1994. Introduction to Animal Parasitology, 3rd ed., Cambridge University Press, Cambridge, 569 pp.

Wagner ED 1954. The life history of Proteocephalus tumidocollus Wagner, 1953, (Cestoda), in rainbow trout. J Parasitol 40: 489-498.

Wedekind C, Jakobsen PJ 1998. Male-biased susceptibility to helminth infection: an experimental test with a copepod. Oikos 81: 458-462. 